\title{
ANALISIS KONTRIBUSI RETRIBUSI PELAYANAN PASAR TERHADAP PENDAPATAN ASLI DAERAH KOTA BAU-BAU
}

\author{
Hasni \\ Program Studi Manajemen, Fakultas Ekonomi \\ Universitas Muhammadiyah Buton, Baubau, Indonesia \\ e-mail: hasni76hasni@gmail.com
}

\begin{abstract}
ABSTRAK
Kota Baubau merupakan salah satu daerah otonom di Provinsi Sulawesi Tenggara. Sejak menjadi daerah otonom, Kota Baubau telah berupaya untuk meningkatkan pembangunan fisik dan non fisik guna meningkatkan pelayanan serta kesejahteraan masyarakat Kota Baubau berdasarkan prinsip keterbukaan, partisipasi atau pertanggung jawaban kepada masyarakat. Oleh sebab itu, dalam hal ini Pemerintah Kota Baubau harus berperan penting dalam upaya menghimpun sumber-sumber penerimaan daerah yang merupakan bagian dari pembangunan daerah yang ada sebagai modal pembangunan daerah.Dari berbagai macam sumber-sumber penerimaan daerah di Kota Baubau, terdapat sumber penerimaan yang berasal dari retribusi daerah yang meliputi retribusi jasa umum, retribusi jasa usaha dan retribusi perizinan. Daerah Provinsi, Kabupaten/Kota diberi peluang dalam menggali potensi sumber-sumber keuangannya dengan menetapkan jenis retribusi selain yang telah ditetapkan, sepanjang memenuhi kriteria yang telah ditetapkan dan sesuai dengan aspirasi masyarakat.

Tujuan penelitian ini adalah untuk mengetahui kontribusi retribusi pelayanan pasar terhadap Pendapatan Asli Daerah Kota Baubau.Alat analisis yang digunakan dalam penelitian ini adalah metode analisis deskriptis kuantitatif.Hasil penelitian menunjukkan bahwa pada tahun 2015 pendapatan Asli daerah yang dikelola oleh pemerintah daerah Kota Baubau sebesar Rp. 28.365.263.333, dan pendapatan retribusi pelayanan pasar Rp. 244.565.250, hal ini menunjukan bahwa kontribusi retribusi pelayanan pasar dalam Pendapatan Asli Daerah adalah sebesar 0,86\%. Pada tahun 2016 pendapatan Asli daerah Kota Baubau sebesar Rp. 34.449.723.144, dan pendapatan retribusi pelayanan pasar Rp. 421.339.450, hal ini menunjukan bahwa kontribusi retribusi pelayanan pasar dalam Pendapatan Asli Daerah adalah sebesar 0,12\%. Pada tahun 2017 pendapatan Asli daerah Kota Baubau sebesar Rp. 50.312.819.293,36 dan pendapatan retribusi pelayanan pasar Rp. 460.751.450, hal ini menunjukan bahwa kontribusi retribusi pelayanan pasar dalam Pendapatan Asli Daerah adalah sebesar $0,91 \%$.
\end{abstract}

Kata Kunci: Pelayanan, Retribusi, Pendapatan Asli Daerah

\begin{abstract}
The city of Baubau is one of the autonomous regions in the province of Southeast Sulawesi. Since becoming an autonomous region, the city has sought to improve physical and non-physical development in order to improve the service and well-being of the people of Baubau based on openness, participation or accountability to society. In this case, the Baubauer Stadtregierung must therefore play an important role in collecting regional sources of income, which are part of the existing regional development as a regional development capital. From various types of regional sources of income in Baubau there are sources of revenue, which arises from regional taxes, the general service fees, service fees for Companies and approval fees include. Provinces, governments / cities will have the opportunity to explore the potential of their financial resources by identifying
\end{abstract}


types of levies other than those specified, provided they meet the criteria set and are in line with Community aspirations.

The purpose of this study was to determine the contribution of market services compensation to the regional income of the city of Baubau. The analysis tool used in this study was a quantitative descriptive analysis method. The results showed that the regional initial income managed by the city of Baubau was in 2015 RP was. 28,365,263,333 and Market Service Retribution Income from RP. $244,565,250$, this shows that the contribution of the market service compensation to the regional original income is $0.86 \%$. In 2016, the original income of the urban area Baubau Rp. 34,449,723,144 and Market Service Retribution Income of RP. 421,339,450, this shows that the contribution of the market service fee to the regional source of original income is $0.12 \%$. In 2017, the original income of the urban area Baubau Rp. 50,312,819,293.36 and Market Service Retribution income of RP. This shows that the contribution of the market service compensation to the regional origin of origin amounts to $0.91 \%$.

Keywords: Service, Retribution, Local Revenue

\section{PENDAHULUAN}

Proses desentralisasi pemerintahan yang dilakukan pemerintah pusat terhadap pemerintah daerah sebagai wujud nyata dari pelaksanaan otonomi daerah memberikan konsekuensi terhadap pemerintah daerah untuk dapat menyelenggarakanpemerintahannya sendiri. Otonomi daerah adalah proses devolusi dalam sektor publik dimana terjadi pengalihan wewenang dari pemerintah pusat kepada pemerintah provinsi dan kabupaten/kota atau proses pelimpahan kekuasaan dari pemerintah pusat kepada pemerintah provinsi dan kabupaten dan kota sebagaimana yang diamanatkan dalam undang-undang.[1]

Kaitannya dalam pemberian otonomi kepada daerah dalam merencanakan, menggali, mengelola dan menggunakaan keuangan daerah sesuai dengan kondisi daerah, Pendapatan Asli Daerah (PAD) dapat sebagai salah satu indikator atau kriteria untuk mengurangi ketergantungan suatu daerah kepada pusat.

Kota Baubau merupakan salah satu daerah otonom di Provinsi Sulawesi Tenggara. Sejak menjadi daerah otonom, Kota Baubau telah berupaya untuk meningkatkan pembangunan fisik dan non fisik guna meningkatkan pelayanan serta kesejahteraan masyarakat Kota Baubau berdasarkan prinsip keterbukaan, partisipasi atau pertanggung jawaban kepada masyarakat. Oleh sebab itu, dalam hal ini Pemerintah Kota Baubau harus berperan penting dalam upaya menghimpun sumber-sumber penerimaan daerah yang merupakan bagian dari pembangunan daerah yang ada sebagai modal pembangunan daerah.Dari berbagai macam sumber-sumber penerimaan daerah di Kota Baubau, terdapat sumber penerimaan yang berasal dari retribusi daerah yang meliputi retribusi jasa umum, retribusi jasa usaha dan retribusi perizinan. Daerah Provinsi, Kabupaten/Kota diberi peluang dalam 
menggali potensi sumber-sumber keuangannya dengan menetapkan jenis retribusi selain yang telah ditetapkan, sepanjang memenuhi kriteria yang telah ditetapkan dan sesuai dengan aspirasi masyarakat [2]. Sementara itu, retribusi daerah adalah pungutan daerah sebagai pembayaran atas jasa atau pemberian izin tertentu yang khusus disediakan atau diberikan oleh pemerintah daerah untuk kepentingan orang pribadi atau badan [3]. Selanjutnya retribusi ialah iuran kepada pemerintah yang dapat dipaksakan dan jasa balik secara langsung dapat ditunjuk. Paksaan yang dimaksud bersifat ekonomis, karena siapa yang tidak merasakan jasa balik pemerintah maka tidak dikenakan iuran [4].

Melihat berbagai sumber penerimaan, maka salah satu retribusi daerah dari golongan retribusi jasa umum terdapat jenis-jenis pelayanan diantaranya adalah retribusi pelayanan pasar. Retribusi adalah pungutan yang dilakukan oleh pemerintah kepada masyarakat sebagai pembayaran atas pemanfaatan jasa atau fasilitas yang disediakan oleh pemerintah [5], kemudian retribusi juga sebagai pembayaran wajib dari penduduk kepada negara karena adanya jasa tertentu yang diberikan oleh negara bagi penduduknya secara perorangan. Jasa tersebut dapat dikatakan bersifat langsung yaitu yang membayar retribusi yang menikmati balas jasa dari negara [6].

Retribusi pasar adalah pungutan yang dilakukan kepada pengguna jasa fasilitas dan prasarana pasar. Jasa tersebut diberikan oleh Pemerintah Daerah kepada pengguna jasa fasilitas dan prasarana pasar. Sebagaimana diketahui dalam setiap tahun retribusi pelayanan pasar memiliki peran dalam meningkatkan pendapatan asli daerah Kota Baubau, karena setiap tahunnya Pemerintah Kota Baubau memiliki target yang ingin dicapai dari penerimaan petribusi pelayanan pasar tersebut. Pendapatan Asli Daerah (PAD) adalah pendapatan yang diperoleh daerah yang dipungut berdasarkan peraturan daerah sesuai dengan peraturan perundang-undangan [7].Pendapatan Asli Daerah merupakan penerimaan yang diperoleh daerah dari sumber-sumber dalam wilayahnya sendiri yang dipungut berdasarkan Undang-undang. Pendapatan Daerah adalah hak pemerintah daerah yang diakui sebagai penambah nilai kekayaan bersih dalam periode tahun anggaran yang bersangkutan [8]. PAD adalah penerimaan yang diperoleh daerah dari sumber-sumber dalam wilayahnya sendiri yang dipungut berdasarkan peraturan daerah sesuai dengan peraturan perundang-undangan yang berlaku [9].Pendapatan Asli Daerah adalah penerimaan pungutan pajak Daerah, pungutan jasa layanan umum, iuran dari penerimaan lain dinas, laba dari perusahaan Daerah dan penerimaan pembangunan Daerah yang digali atau dihasilkan oleh Daerah yang bersangkutan [10]. 
Target yang telah ditetapkan oleh Pemerintah Kota Baubau merupakan hasil realisasi dari penerimaan retribusi pelayanan pasar. Dengan demikian dapat diketahui besarnya dana yang diperoleh dari retribusi pelayanan pasar yang mana dalam hal ini, dengan adanya penerimaan retribusi pelayanan pasar tersebut,maka akan meningkatkan Pendapatan Asli Daerah (PAD) Kota Baubau. Hal ini berarti bahwa retribusi pelayanan pasar dapat mendukung proses pembangunan dan kesejahteraan masyarakat Kota Baubau. Berdasarkan uraian latar belakang diatas, sehingga penulis tertarik untuk melakukan penelitian dengan judul "Analisis Kontribusi Retribusi Pelayanan Pasar Terhadap Pendapatan Asli Daerah Kota Baubau”.

\section{METODE PENELITIAN}

Penelitian ini dilakukan pada Kantor Badan Pengelolaan Keuangan, Aset dan Pendapatan Daerah Kota Baubau Sulawesi Tenggara. Populasi adalah keseluruhan objek penelitian yang memiliki karakteristik tertentu. [11]. Populasi dalam penelitian ini adalah data Laporan Realisasi Penerimaan Pendapatan Asli Daerah Kota Baubau. Sampel adalah sejumlah anggota yang dipilih dari populasi [12]. Data sampel yang digunakan adalah data Pendapatan Asli Daerah Tahun 2015 sampai dengan Tahun 2017, dengan sumber data primer dan sekunder.

Penelitian ini memiliki tujuan, maka untuk mencapai tujuan tersebut, maka metode analisis yang digunakan adalah metode analisis kuantitatif. Metode Penelitian Kuantitatif adalah sebagai berikut: "Metode penelitian yang berlandaskan pada filsafat positivisme, digunakan untuk meneliti pada populasi atau sampel tertentu, pengumpulan data menggunakan instrumen penelitian, analisis data bersifat kuantitatif atau statistik, dengan tujuan untuk menguji hipotesis [13].

Metode analisis kuantitatif berdasarkan pada perhitungan matematika yang dapat diukur, kemudian diolah dengan menggunakan rumus-rumus yang dapat diambil dari buku-buku literatul sesuai dengan permasalahan yang akan diteliti.Untuk mengetahui kontribusi dari retribusi pasar terhadap pendapatan asli daerah [14], rumus yang digunakan adalah sebagai berikut:

$$
\text { Kontribusi }=\frac{\text { Realisasi penerimaan Retribusi Pasar Tahun ke }-n}{\text { Pendapatan Asli Daerah Tahun ke }-n} \times 100 \%
$$




\section{HASIL DAN PEMBAHASAN}

\section{a. Hasil Penelitian}

\section{1) Pendapatan Asli Daerah Kota Baubau}

Pendapatan Asli Daerah (PAD) Kota Baubau adalah merupakan penerimaan yang diperoleh pemerintah daerah Kota Baubau yang bersumber dari dalam wilayahnya sendiri yang dipungut berdasarkan Undang-undang untuk dipergunakan sebagai dana pembiayaan pembangunan. Dalam tiga tahun terakhir yaitu tahun 2015, 2016 dan 2017 Pendapatan Asli Daerah Kota Baubau terus mengalami perubahan (berfluktuasi), kondisi tersebut dapat dilihat pada tabel sebagai berikut:

Tabel 1. Pendapatan Asli Daerah Kota Baubau Tahun 2015, 2016, 2017 (Dalam Rupiah)

\begin{tabular}{|c|l|l|l|l|}
\hline \multirow{2}{*}{ No } & \multicolumn{2}{|c|}{ Keterangan } & \multicolumn{3}{c|}{ Pendapatan Asli Daerah(PAD) } \\
\cline { 3 - 5 } & & \multicolumn{1}{c|}{ Tahun 2015 } & \multicolumn{1}{c|}{ Tahun 2016 } & \multicolumn{1}{c|}{ Tahun 2017 } \\
\hline 1 & Pajak Daerah & 13.389 .629 .039 & 18.387 .214 .641 & 36.177 .482 .751 \\
\hline 2 & Retribusi Daerah & 429.608 .350 & 343.589 .800 & 246.838 .000 \\
\hline 3 & $\begin{array}{l}\text { Hasil Pengelolaan kekayaan } \\
\text { daerah yang di pisahkan }\end{array}$ & 2.344 .173 .608 & 4.604 .692 .565 & 5.244 .817 .238$. \\
\hline 4 & Lain-lain Pendapatan Asli Daerah & 12.201 .852 .336 & 11.114 .226 .138 & $8.643 .681 .304,36$ \\
\hline \multicolumn{1}{|c|}{ Jumlah } & $\mathbf{2 8 . 3 6 5 . 2 6 3 . 3 3 3}$ & $\mathbf{3 4 . 4 4 9 . 7 2 3 . 1 4 4}$ & $\mathbf{5 0 . 3 1 2 . 8 1 9 . 2 9 3 , 3 6}$ \\
\hline
\end{tabular}

Sumber: Dispenda Kota Baubau (Data diolah)

Tabel 1 di atas menunjukan bahwa pada tahun 2015 Pendapatan Asli Daerah kota Baubau mencapai Rp 28.365.263.333. Pendapatan tersebut berasal dari penerimaan Pajak Daerah, Retribusi Daerah, Hasil Pengelolaan Kekayaan Daerah yang Dipisahkan dan Lain-lain Pendapatan Asli Daerah.Pada tahun 2016 Pendapatan Asli Daerah Kota Baubau mengalami kenaikan sebesar Rp. 6.084.459.811 sehingga pada tahun tersebut Pendapatan Asli Daerah Kota Baubau menjadi Rp. 34.449.723.144. Secara umum peningkatan Pendapatan Asli Daerah Kota Baubau dari tahun 2015 ke tahun 2016 disebabkan oleh kenaikan penerimaan Hasil pengelolaan kekayaan daerah yang dipisahkan yaitu sebesar Rp. 2.260.518.957. Sedangkan pada tahun 2017 Pendapatan Asli Daerah Kota Baubau Mengalami peningkatan yaitu sebesar Rp. 15.863.096.149,36 sehingga Pendapatan Asli daerah Kota Baubau pada tahun 2017 menjadi Rp. 
50.312.819.293,36.Peningkatan ini disebabkan oleh meningkatnya jumlah pendapatan pajak Daerah tiap tahunnya.

\section{(1) Retribusi Pelayanan Pasar}

Peraturan Daerah Kota Baubau menjelaskan bahwa retribusi pasar yang selanjutnya disebut retribusi pelayanan pasar adalah pembayaran atas penggunaan pemakaian dan pemanfaatan kios, los atau toko dikawasan pasar dan tempat perdagangan umum yang disediakan oleh Pemerintah Daerah [11]. Dalam tiga tahun terakhir yaitu tahun 2015, 2016 dan 2017 pendapatan retribusi pelayanan pasar yang diterima oleh pemerintah Kota Baubau mengalami fluktuasi, kondisi tersebut dapat dilihat pada tabel sebagai berikut:

Tabel 2.Pendapatan Retribusi Pelayanan Pasar Kota Baubau Tahun 2015, 2016, 2017 (Dalam Rupiah)

\begin{tabular}{|c|l|l|l|l|}
\hline \multirow{2}{*}{ No } & \multirow{2}{*}{ Keterangan } & \multicolumn{3}{|c|}{ Retribusi Pelayanan Pasar } \\
\cline { 3 - 5 } & & \multicolumn{1}{|c|}{ Tahun 2015 } & \multicolumn{1}{|c|}{ Tahun 2016 } & Tahun 2017 \\
\hline 1 & Pasar buah & 38.460 .000 & 25.680 .000 & 21.720 .000 \\
\hline 2 & PKD Pasar Wameo & 8.820 .000 & 14.200 .000 & 12.480 .000 \\
\hline 3 & Pasar-Los & 125.285 .250 & 128.959 .450 & 119.051 .450 \\
\hline 4 & Pasar-Kios & 72.000 .000 & 252.500 .000 & 307.500 .000 \\
\hline \multicolumn{2}{|c|}{ Jumlah } & $\mathbf{2 4 4 . 5 6 5 . 2 5 0}$ & $\mathbf{4 2 1 . 3 3 9 . 4 5 0}$ & $\mathbf{4 6 0 . 7 5 1 . 4 5 0}$ \\
\hline
\end{tabular}

Sumber: Dispenda Kota Baubau

Berdasarkan tabel 2 di atas, maka data yang diperoleh selama penyelenggaraan retribusi pasar dari tahun 2015 sampai tahun 2017 menyatakan bahwa angka realisasi retribusi pelayanan pasar Kota Baubau tiap tahunnya mengalami fluktuasi

(2) Kontribusi Retribusi Pelayanan Pasar Terhadap Pendapatan Asli Daerah Kota Baubau

Retribusi pasar yang diselenggarakan oleh pemerintah daerah Kota Baubau merupakan salah satu sumber penerimaan bagi Pendapatan Asli daerah Kota Baubau, retribusi pasar memberikan kontribusi tersendiri dalam Pendapatan Asli Daerah Kota Baubau.Semakin besar nilai kontribusi retribusi pasar 
menunjukkan bahwa semakin besar pula peranan retribusi pasar dalam meningkatkan Pendapatan Asli Daerah Kota Baubau.

Berikut perhitungan kontribusi retribusi pelayanan pasar dalam Pendapatan Asli Daerah Kota Baubau:

$$
\begin{aligned}
& \text { Tahun } 2015=\frac{244.565 .250}{28.365 .263 .333} \times 100 \%=0,86 \\
& \text { Tahun } 2016=\frac{421.339 .450}{34.449 .723 .144} \times 100 \%=0,12 \\
& \text { Tahun } 2017=\frac{460.751 .450}{50.312 .819 .293,36} \times 100 \%=0,91
\end{aligned}
$$

Tabel 3. Kontribusi Retribusi Pelayanan Pasar terhadap Pendapatan Asli Daerah Kota Baubau

\begin{tabular}{|c|c|c|c|c|}
\hline No & Tahun & $\begin{array}{c}\text { Retribusi Pasar } \\
(\mathbf{R p})\end{array}$ & $\begin{array}{c}\text { Pendapatan Asli Daerah } \\
(\mathbf{R p})\end{array}$ & $\begin{array}{c}\text { Kontribusi } \\
(\boldsymbol{\%})\end{array}$ \\
\hline 1 & 2015 & 244.565 .250 & 28.365 .263 .333 & 0,86 \\
\hline 2 & 2016 & 421.339 .450 & 34.449 .723 .144 & 0,12 \\
\hline 3 & 2017 & 460.751 .450 & $50.312 .819 .293,36$ & 0,91 \\
\hline
\end{tabular}

Sumber: Dispenda Kota Baubau (Data diolah)

Tabel 3 menunjukan bahwa pada tahun 2015 pendapatan Asli daerah yang dikelola oleh pemerintah daerah Kota Baubau sebesar Rp. 28.365.263.333, dan pendapatan retribusi pelayanan pasar Rp.244.565.250, hal ini menunjukan bahwa kontribusi retribusi pasar terhadap Pendapatan Asli Daerah adalah sebesar 0,86\%. Pada tahun 2016 pendapatan Asli daerah Kota Baubau sebesar Rp34.449.723.144dan pendapatan retribusi pasar Rp.421.339.450, hal ini menunjukan bahwa kontribusi retribusi pasar terhadap Pendapatan Asli Daerah adalah sebesar 0,12\%. Pada tahun 2017 pendapatan Asli daerah Kota Baubau sebesar Rp. 50.312.819.293,36dan pendapatan retribusi pasar Rp. 460.751.450, hal ini menunjukan bahwa kontribusi retribusi pasar terhadap Pendapatan Asli Daerah adalah sebesar 0,91\%.

Berdasarkan tabel 3 di atas diketahui bahwa hasil penerimaan retribusi pelayanan pasar terhadap pendapatan asli daerah kota baubau tertinggi terjadi 
pada tahun 2017 yaitu sebesar 0,91\% dan terendah terjadi pada tahun 2016 yaitu sebesar $0,12 \%$.

\section{b. Pembahasan}

Berdasarkan hasil realisasi retribusi pelayanan pasar yang dikelola oleh pemerintah daerah Kota baubau, realisasinya menunjukan peningkatan terhadap penerimaan retribusi pelayanan pasar disetiap tahunnya. Namun hasil dari realisasi retribusi pelayanan pasar yang dikelola pemerintah belum mencapai target yang telah ditentukan oleh pemerintah daerah,. Dalam hal ini, mungkin disebabkan oleh kurangnya pelayanan jasa fasilitas terhadap pedagang serta turunnya kesadaran masyarakat akan wajib retribusi, terbatasnya jumlah juru tagih dalam hal pemungutan retribusi pelayanan pasar, banyak toko/ruko, lapak, kios, los dan pedagang yang tutup sehingga pedagang yang tidak berdagang lepas dari penarikan retribusi harian yang memungkinkan kurang efektif serta efisiennya dalam pengelolaan maupun pemungutan potensi retribusi pelayanan pasar dalam meningkatkan pendapatan asli daerah kota Baubau.

Sementara itu, hasil perhitungan kontribusi retribusi pelayanan pasar terhadap pendapatan asli daerah kota baubau tahun anggaran 2015 sampai tahun 2017, terlihat bahwa jumlah penerimaan realisasi retribusi pelayanan pasar menunjukan peningkatan di tahun 2017. Akan tetapi, kontribusi retribusi pelayanan pasar memiliki kontribusi yang sangat kurang atau hanya mampu berkontribusi dengan rata-rata $1,89 \%$ terhadap pendapatan asli daerah kota baubau. Untukmeningkatkan penerimaan retribusi pelayanan pasar, pemerintah harus mengoptimalkan kinerja petugas pemungut dalam penerimaan retribusi pelayanan pasar serta mencari sumber-sumber potensi baru yang dijadikan sumber penerimaan baru khususnya sebagai penerimaan retribusi pelayanan pasar sehingga kedepannya retribusi pelayanan pasar dapat meningkat dalam segi kontribusinya terhadap pendapatan asli daerah kota Baubau.

\section{KESIMPULAN}

Berdasarkan hasil penelitian dan pengamatan yang dilakukan serta didukung oleh data-data yang diperoleh dari Dinas Pendapatan Daerah Kota Baubau, maka kesimpulan dalam penelitian ini, yaitu: kontribusi yang diberikan oleh retribusi pelayanan pasar 
terhadap pendapatan asli daerah kota baubau pada tahun 2015 sebesar 0,86\%.Pada tahun 2016 retribusi pelayanan pasar memberikan kontribusi dalam pendapatan asli daerah Kota Baubau sebesar 0,12\%. Pada tahun 2017 kontribusi retribusi pelayanan pasar dalam pendapatan asli daerah kota baubau sebesar $0,91 \%$.

Kontribusi retribusi pelayanan pasar terhadap pendapatan asli daerah kota baubau yang dikelola oleh Dinas pendapatan Daerah masih tergolong sangat kecil, sedangkan berdasarkan hasil analisis trend dengan pengelolaan data yang dilakukan memperoleh hasil analisis trend terhadap retribusi pelayanan pasar kota Baubau, dengan prospek yang bergerak positif selama tiga tahun terakhir ini.

\section{SARAN}

Berdasarkan kesimpulan yang didapatkan, maka saran dalam penelitian ini adalah pemerintah daerah sebaiknya melakukan penyuluhan atau pemberitahuan tentang pentingnya membayar retribusi daerah seperti retribusi pelayanan pasar, sehingga diharapkan dengan adanya hal tersebut dapat meningkatkan kepatuhan membayar retribusi. Selain itu di harapkan pemerintah daerah untuk bekerja sama dengan pihakpihak yang berhubungan dengan kegiatan perdagangan, pariwisata, perindustrian agar dapat bersama-sama memikirkan langkah-langkah yang tepat demi memajukan penerimaan pendapatan asli daerah kota Baubau

\section{DAFTAR PUSTAKA}

[1] Mas'ud Said, Arah Baru Otonomi Daerah di Indonesia ( Malang: UPT Penerbitan Universitas Muhammadiyah Malang, 2008

[2] Yani, Ahmad. 2002. Konsep Retribusi Daerah dan Pendapatan Asli Daerah.Jakarta: PT Gramedia.

[3] Halim,Abdul dan Muh. Iqbal. 2012. Analisis Retribusi Daerah. Jakarta:Salemba Empat.

[4] Munawir. 2002.Tata Cara Pemungutan Retribusi. BPEE UGM.Yogyakarta.

[5] Mardiasmo. 2011. Retribusi. Edisi Revisi. Yogyakarta:Andi Offset.

[6] Siahaan, Marihot P. 2005. Pajak Daerah dan Retribusi Daerah.Jakarta:Raja Grafindo Persada.

[7] Undang-Undang Nomor 33 Tahun 2004 tentang Perimbangan Keuangan Antara Pusat dan Daerah.

[8] Djumhana. 2007. Pengantar Hukum Pendapatan Asli Daerah. Bandung:Citra Aditya Bakti. 
[9] Halim,Abdul. 2004. Pendapatan Asli Daerah. Edisi Keempat.Jakarta: Salemba Empat.

[10] Devas. 2003. Pendapatan Asli Daerah. Yogyakarta:Andi.

[11] Usman Rianse dan Abdi. 2009. Metodologi Penelitian Sosial dan Ekonomi. Bandung : Alfabeta.

[12] Sekaran, Uma. (2011). Research Methods for business Edisi I and 2. Jakarta: Salemba Empat

[13] Sugiyono. 2012. Metode Penelitian Kuantitatif Kualitatif dan R\&D. Bandung: Alfabeta.

[14] Peraturan Daerah Kota Baubau Nomor 26 Tahun 2012 tentang Retribusi Pelayanan Pasar. 